\title{
Acquired Hypothyroidism in Patients with Metastatic Renal Cell Carcinoma Treated with Tyrosine Kinase Inhibitors
}

This article was published in the following Dove Press journal:

Drug Design, Development and Therapy

\section{Jialu $\mathrm{Wu}$}

Hui Huang

Sichuan University, Department of Endocrinology and Metabolism, West China Hospital, Chengdu 610064, Sichuan Province, People's Republic of China

Correspondence: Hui Huang Department of Endocrinology and Metabolism, West China Hospital, 37 Guoxue Lane, Chengdu 61004I, Sichuan Province, People's Republic of China $\mathrm{Tel} / \mathrm{Fax}+862885422982$

Email sansan1880@I26.com
Purpose: We analyze a number of studies that describe the relationship between the onset of hypothyroidism and the prognosis of patients with metastatic renal cell carcinoma (mRCC) treated with TKIs.

Patients and Methods: Targeted therapies are currently considered as the first-line treatment for patients with mRCC. The occurrence of hypothyroidism in the treatment of mRCC with TKIs is a major side effect. A comprehensive search was performed in Pubmed, Cochrane Library, Institute for Scientific Information, and CKNI. The following keywords and descriptors were used during the search and were combined in a number of sequences in English and Chinese languages: protein kinase inhibitors (including sunitinib, pazopanib, tivozanib, cabozantinib, axitinib, sorafenib), hypothyroidism and renal cell carcinoma.

Results: Scholars have studied the clinical relationship between hypothyroidism and TKI treatment and its molecular biology mechanism. Most studies hold that hypothyroidism occurring during TKI therapy may serve as potential biomarkers of response and efficacy of treatment, but there is no consensus on this point.

Conclusion: The mechanism of hypothyroidism occurring is still unclear. Therefore, more studies are needed to clarify whether better outcomes are associated with TKI-induced hypothyroidism in mRCC patients, helping to maximize the treatment outcome of mRCC patients.

Keywords: metastatic renal cell carcinoma, mRCC, tyrosine kinase inhibitors, TKIs, hypothyroidism, progression-free survival, PFS, overall survival, OS

\section{Introduction}

Renal cell carcinoma (RCC) represents approximately 3\% of all cancers. ${ }^{1}$ Some patients with RCC have distant metastases at the time of initial diagnosis. ${ }^{2}$ In the past 2 decades, there was an annual increase of $2 \%$ incidence worldwide. ${ }^{1}$ Historically, the patients with metastatic renal cell carcinoma (mRCC) had a poor prognosis $^{3}$ for the insensitivity of $\mathrm{mRCC}$ to radiation and chemotherapy. And surgery was nearly the only standard treatment of localized renal tumor. ${ }^{4}$

Tyrosine kinase inhibitors (TKIs) have been recognized as the first-line treatment of mRCC since 2005, which significantly improve overall survival (OS) and progression-free survival (PFS). A potential side effect of TKIs is the development of hypothyroidism, several studies showed an incidence of hypothyroidism varies from 14 to $70 \%$ in mRCC patients treated with sunitinib-a kind of TKIs, but the mechanism was clear. ${ }^{5}$ Some scholars indicated that hypothyroidism might serve as 
potential predictive biomarkers of treatment efficacy. However, the hypotheses are still controversial. ${ }^{5}$

The aim of this literature review is to evaluate the relationships between acquired hypothyroidism by TKIs and the outcome in patients with mRCC. We focus on whether the emergence of hypothyroidism could be one of the indicators suggesting the prognosis of mRCC patients or not.

\section{Materials and Methods}

The literature search was conducted using the following electronic databases: Pubmed, Cochrane Library, Institute for Scientific Information (ISI), and CKNI from January 2005 to November 2019. The databases were consulted to screen out the literatures that specifically focused on hypothyroidism and its potential influence on the outcome of mRCC patients treated with TKIs. The following keywords and descriptors were used during the search and were combined in a number of sequences in English and Chinese languages: protein kinase inhibitors (including sunitinib, pazopanib, tivozanib, cabozantinib, axitinib, sorafenib), hypothyroidism and renal cell carcinoma. The selected studies were chosen based on their title and abstract description. Papers were excluded, which focused on comparing the relationship between hypothyroidism and other carcinoma or did not study the relationship between hypothyroidism and prognosis.

\section{Literature Review}

\section{Application of TKIs in the Treatment of mRCC}

Renal cell carcinoma (RCC) includes different subtypes, endowed with a completely different prognosis, with the most frequent being clear cell (ccRCC 70-80\%). ${ }^{6}$ About $90 \%$ of sporadic ccRCC is detected the mutations or methylation of von Hippel-Lindau (VHL) genes, which regulate the secretion of vascular endothelial growth factor (VEGF). ${ }^{7}$ Hypoxia-inducible factors containing VHL complexes degrade themselves automatically in normal cells. But in ccRCC, owing to the dysfunction of VHL complexes, hypoxia-inducible factors accumulate in cells, then activate their downstream hypoxia-driven genes, that including VEGF and other factors involved in angiogenesis, cell growth, and survival, ultimately leading to glucose metabolism confusion, programmed cell death, vascular proliferation, and endothelial stability. ${ }^{8}$ Based on it, targeted vascular endothelial growth factor/receptor- tyrosine kinase inhibitors (VEGF/R-TKI) are used in the treatment of mRCC.

Previous studies have highlighted that TKIs could inhibit cellular signaling by targeting multiple receptor tyrosine kinases (RTKs), including the receptors of platelet-derived growth factor (PDGF) and VEGF. ${ }^{5}$ TKIs could directly or indirectly inhibit vascularisation of tumors and reducing the volume of tumors. While, the underlying mechanism of action of TKIs is complex and still not enough clear, and the mechanism of action of different kinds of TKIs is not the same.

According to the 2019 National Comprehensive Cancer Network (NCCN) meeting, the most commonly used firstline anti-VEGF targeting drugs were sunitinib, sorafenib, and pazopanib. ${ }^{9}$ The European Association of Urology (EAU) renal cell cancer guidelines suggested that sunitinib and pazopanib, both as the first-line anti-VEGF targeting drugs for RCC, could improve PFS and/or OS in patients with mRCC. ${ }^{1}$ TARGET study, a Phase III, randomized, double-blind, placebo-controlled trial, showed that the objective response rate of sorafenib in the treatment of mRCC was $11 \%$, and the clinical benefit ratio was $84 \%$. Compared with placebo, sorafenib significantly prolonged the PFS of mRCC patients about 2.7 months and significantly prolonged OS about 3.5 months. ${ }^{10}$ An international multicenter, randomized, Phase III clinical trial conducted by Motzer et al, comparing the efficacy of sunitinib and IFN- $\alpha$ in 750 mRCC patients, PFS were 11 months in the sunitinib group and 5 months in IFN- $\alpha$ group $(\mathrm{P}<0.0001)$; the objective response ratio were $47 \%$ and $12 \%$, respectively $(\mathrm{P}<0.0001) .{ }^{11}$ Sternberg et al performed a randomized, double-blind phase III clinical trial, showing that pazopanib monotherapy prolonged PFS compared with the patients who did not receive treatment ever (11.1 months vs 2.8 months, $\mathrm{P}<0.001) .{ }^{12}$

With the advent of targeted drug therapy for mRCC and the confirmation of its effectiveness of the improving OS and/or PFS, patients could receive longer treatment. Therefore, the adverse events (AEs) caused by TKIs have attracted much more attention, raising challenges in their management.

\section{Hypothyroidism Induced by TKIs Incidence of Hypothyroidism}

Thyroid abnormalities are reported by the use of TKIs such as sunitinib, sorafenib, pazopanib, or others in the class. The most common of abnormality is hypothyroidism, rarely requiring hormone replacement therapy or to 
suspend the use of TKIs drugs. ${ }^{13}$ Thyroid hormones play an important role in the growth, metabolism, and maintenance excitability of the central nervous system. The clinical manifestations of hypothyroidism vary, including a subclinical or overt profile. The incidence rates of hypothyroidism reported by different studies were different, ranging from $14 \%$ to $70 \%$. These may be partly be associated with their different clinical observation time or various treatment strategies. For example, with sunitinib, the incidence of hypothyroidism is initially reported at $14 \%$ in a phase III clinical trial; however, other studies suggest that the incidence may be more than $50 \%{ }^{13}$ Longer use time means better observation of drug efficacy and adverse reactions, which means closer to the actual results.

\section{Possible Mechanism of Hypothyroidism}

The mechanism of the development of hypothyroidism in patients receiving TKIs are not yet clearly clarified, but some evidence and hypotheses have been put forward: VEGF/R-TKIs block thyroid hormone biosynthesis through thyroid peroxidase inhibition (may react as a noncompetitive inhibitor) ${ }^{14}$ increasing type 3 deiodination, ${ }^{15}$ TKIs influence iodothyronine transport through inhibiting transmembrane transport of thyroid derived hormones, ${ }^{16}$ TKIs inhibit VEGF signaling to reduce fenestration number in thyroid capillary, induce thyroidal capillary regression and progressively deplete thyroid's functional reserve. ${ }^{17,18}$ Such as sunitinib, a multitarget tyrosine kinase inhibitor, affects these pathways involved in angiogenesis, apoptosis, or cell proliferation, such as vascular endothelial growth factor receptor (VEGFR), plateletderived growth factor (PDGF) and so on. ${ }^{19}$ Whether TKIrelated hypothyroidism is mediated by inhibition of the VEGF pathway or of other molecular pathways is unknown yet.

In fact, the molecular background of thyroid dysfunction in the treatment of RCC is elusive. Recent studies have suggested that a hypothyroid state may suppress cancer, while excessive thyroid hormone can stimulate its growth. ${ }^{20}$ Thyroid hormone also causes hyperplasia of human skin microvascular endothelial cells and the formation of new blood vessels. ${ }^{20}$ This suggests that endogenous thyroid hormones may be growth factors for several types of tumors. ${ }^{21}$ As a highly biologically active thyroid hormone, triiodothyronine (T3) plays an important role in the regulation of renal cell growth, differentiation, and metabolism, just as a study, it had shown that T3 could induce the expression of its EGFR gene in renal tubular cells in RCC, thus leading to potentiate mitogenic stimulation of epidermal growth factor (EGF). ${ }^{22}$ As reported earlier, upon stimulation of TR $\beta$, cells secreted VEGF and basic fibroblast growth factor. ${ }^{23}$ That is to say, the thyroid hormone had a promoting effect on tumor cell growth, and hypothyroid state might have an inhibitive effect on tumor cells to a certain extent.

In vitro, Kappers's study results showed that sunitinib caused marked regression of thyroid capillaries in rats, which might explain the occurrence of hypothyroidism by TKIs drugs. ${ }^{24}$ In mice, the administration of an experimental VEGF receptor inhibitor or soluble VEGF receptor was associated with pronounced regression of capillaries in the thyroid gland and marked increase in serum TSH levels, which was called capillary regression hypothesis. ${ }^{17}$ Llanyee's study showed that sunitinib did not block thyroid peroxidase in patients with $\mathrm{mRCC}{ }^{25}$ Mannavola et al found that hypothyroidism was related to inhibition of iodine uptake $^{26}$ when evaluating the effects of sunitinib on thyroid function with gastrointestinal stromal tumors. But Andrew's in vitro studies with rat thyroid cells proposed that sunitinib was unlikely to cause hypothyroidism by inhibition of iodide uptake. ${ }^{27}$ De Groot's study had pointed out that sunitinib, might act as the same mechanism as imatinib, inducing liver enzymes involved in the catabolism of FT3 and FT4, with most of it being metabolized by sequential deiodination. ${ }^{28}$ But no changes in the levels of FT3 and FT4 were observed in Baldazzi et al's studies. ${ }^{29}$

Researchers have hypothesized that the occurrence of hypothyroidism might be due to the direct toxicity of TKIs to the thyroid gland. However, as Baldazzi's clinical studies have found, a patient receiving both sunitinib for mRCC and thyroid hormone replacement for earlier total thyroidectomy was observed to have a TSH level elevation. ${ }^{29}$ This finding suggested that the change of thyroid function was completely unrelated to the thyroid gland itself. The interference of the hypothalamic-pituitary -thyroid axis was considered unrelated to hypothyroidism since no other relevant hormone abnormalities have been recorded in such cases. ${ }^{26,29}$

Therefore, the cause of hypothyroidism during the course of treatment with TKI is still not fully understood, and more researches are needed to confirm it.

\section{The Relationship Between Hypothyroidism and Prognosis}

Hypothyroidism is suspected to be able to serve as a predictive factor for the outcome of TKI therapy for 
Table I Current Analysis of TKIs and Prognosis

\begin{tabular}{|c|c|c|c|c|c|c|c|c|}
\hline Researcher & Year & Study Type & TKIs & $\begin{array}{l}\text { Patients } \\
\text { Number }\end{array}$ & $\begin{array}{l}\text { Incidence of } \\
\text { Hypothyroidism }\end{array}$ & PFS (Months) & OS & Comparison Object \\
\hline 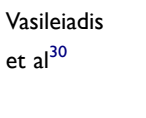 & 2019 & Retrospective & Sunitinib & 70 & $30(42.86 \%)$ & $\begin{array}{l}\text { II.92 vs. } 8.63 \\
(p=0.0476)\end{array}$ & $\begin{array}{l}3.10 \text { vs. } \\
1.08 \text { years } \\
(p=0.0011)\end{array}$ & $\begin{array}{l}\text { Patients had a day- } 15 / \text { baseline } \\
\text { TSH ratio }<2 \text { vs. patients had } \\
\text { a day- } 15 / \text { baseline } \mathrm{TSH} \text { ratio }<2\end{array}$ \\
\hline $\begin{array}{l}\text { Buda Nowak } \\
\text { et } \mathrm{al}^{33}\end{array}$ & 2017 & Retrospective & Sunitinib & 27 & $12(44 \%)$ & $\begin{array}{l}28.3 \text { vs. } 9.8 \\
(p=0.022)\end{array}$ & NG & $\begin{array}{l}\text { Hypothyroid vs. euthyroid } \\
\text { patients }\end{array}$ \\
\hline Bailey et al $^{15}$ & 2015 & Retrospective & $\begin{array}{l}\text { VEGFR-TKIs } \\
\text { (Sunitinib/ } \\
\text { sorafenib/ } \\
\text { pazopanib/ } \\
\text { axitinib) }\end{array}$ & 65 & $25(38.5 \%)$ & $\begin{array}{l}47.7 \text { vs. } 9.3 \\
(P=0.009)\end{array}$ & $\begin{array}{l}\text { Not } \\
\text { reached vs. } \\
21.4 \\
\text { months } \\
(P=0.005) .\end{array}$ & $\begin{array}{l}\text { Severe hypothyroidism }(\mathrm{TSH}>10 \\
\mathrm{mIU} / \mathrm{L}) \text { vs. combined } \\
\text { euthyroidism and mild } \\
\text { hypothyroidism (TSH } \leq 10 \mathrm{mlU} / \mathrm{L})\end{array}$ \\
\hline Kust et $\mathrm{al}^{5}$ & 2014 & Retrospective & Sunitinib & 41 & $12(29.3 \%)$ & $\begin{array}{l}25.3 \text { vs. } 9.0 \\
(p=0.042)\end{array}$ & $\begin{array}{l}46.0 \text { vs. } \\
22.1 \\
\text { months } \\
(p=0.2052)\end{array}$ & $\begin{array}{l}\text { Patients with } \mathrm{TSH}>4 \mathrm{mlU} / \mathrm{L} \text { and } \\
\text { receiving levothyroxine vs. all } \\
\text { other patients }\end{array}$ \\
\hline Sella et $\mathrm{al}^{22}$ & 2012 & Retrospective & Sunitinib & 31 & $16(52 \%)$ & $\begin{array}{l}12.2 \text { vs. } 9.4(p= \\
0.234)\end{array}$ & $\begin{array}{l}22.4 \text { vs. } \\
13.9 \\
\text { months ( } P \\
=0.234)\end{array}$ & $\begin{array}{l}\text { Hypothyroid vs. euthyroid } \\
\text { patients }\end{array}$ \\
\hline $\begin{array}{l}\text { Sabatier } \\
\text { et } \mathrm{al}^{20}\end{array}$ & 2012 & $\begin{array}{l}\text { Prospective } \\
\text { observational } \\
\text { multicenter }\end{array}$ & Sunitinib & 107 & $\begin{array}{l}54(53 \%) \text { (102 with } \\
\text { normal baseline) }\end{array}$ & $\begin{array}{l}18.9 \text { vs. } 15.9(P= \\
0.94)\end{array}$ & NG & $\begin{array}{l}\text { Patients with abnormal thyroid } \\
\text { function vs. normal thyroid } \\
\text { function }\end{array}$ \\
\hline $\begin{array}{l}\text { Clemons } \\
\text { et } \mathrm{al}^{35}\end{array}$ & 2012 & $\begin{array}{l}\text { Retrospective } \\
\text { chart review }\end{array}$ & $\begin{array}{l}\text { Sunitinib/ } \\
\text { Sorafenib }\end{array}$ & 61 & $\begin{array}{l}15 / 34(44 \%) \\
\text { sunitinib } 6 / 22 \\
(27 \%) \text { sorafenib }\end{array}$ & $\begin{array}{l}\text { I8.2 vs. } 10.1 \\
(P=00.01)\end{array}$ & NG & $\begin{array}{l}\text { Hypothyroid vs. euthyroid } \\
\text { patients }\end{array}$ \\
\hline $\begin{array}{l}\text { Baldazzi } \\
\text { et } \mathrm{al}^{29}\end{array}$ & 2012 & $\begin{array}{l}\text { Prospective } \\
\text { single-center }\end{array}$ & Sunitinib & 22 & $13(59.1 \%)$ & $\begin{array}{l}8.55 \text { vs. } 7.03 \\
(P<0.05)\end{array}$ & NG & $\begin{array}{l}\text { Hypothyroid vs. euthyroid } \\
\text { patients }\end{array}$ \\
\hline $\begin{array}{l}\text { Ismael Pinto } \\
\text { et } \mathrm{al}^{34}\end{array}$ & 2012 & Retrospective & Sunitinib & 50 & $20(40 \%)$ & $\begin{array}{l}21.7 \text { and } 14.2 \\
(p<0.000 I)\end{array}$ & NG & $\begin{array}{l}\text { Hypothyroid vs. euthyroid } \\
\text { patients }\end{array}$ \\
\hline $\begin{array}{l}\text { Riesenbeck } \\
\text { et } \mathrm{al}^{36}\end{array}$ & 2011 & Prospective & $\begin{array}{l}\text { Sorafenib/ } \\
\text { sunitinib }\end{array}$ & 83 & $\begin{array}{l}31(37.3 \%) \\
\text { sorafenib } 52 \\
(62.7 \%) \text { sunitinib }\end{array}$ & $\begin{array}{l}16.0 \text { vs. } 6.0 \\
(P=0.032)\end{array}$ & NG & $\begin{array}{l}\text { Hypothyroid vs. euthyroid } \\
\text { patients }\end{array}$ \\
\hline $\begin{array}{l}\text { Schmidinger } \\
\text { et } \mathrm{al}^{32}\end{array}$ & 2011 & Prospective & $\begin{array}{l}\text { Sunitinib/ } \\
\text { sorafenib }\end{array}$ & $83^{a} 78^{b}$ & $30(36.1 \%)^{a}$ & $\begin{array}{l}\text { I7.0 vs. } 10.8 \\
(P=0.53)^{b}\end{array}$ & $\begin{array}{l}\text { NR vs. } 13.9 \\
\text { months } \\
(P=0.016)^{a}\end{array}$ & $\begin{array}{l}\text { Hypothyroid vs. euthyroid } \\
\text { patients }\end{array}$ \\
\hline $\begin{array}{l}\text { P. Wolter } \\
\text { et } \mathrm{al}^{31}\end{array}$ & 2008 & Prospectively & Sunitinib & 40 & $28(70 \%)$ & $\begin{array}{l}10.3 \text { vs. } 3.6 \\
(P=0.047)\end{array}$ & $\begin{array}{l}18.2 \text { versus } \\
6.6 \\
(P=0.13)\end{array}$ & $\begin{array}{l}\text { Hypothyroid vs. euthyroid } \\
\text { patients }\end{array}$ \\
\hline
\end{tabular}

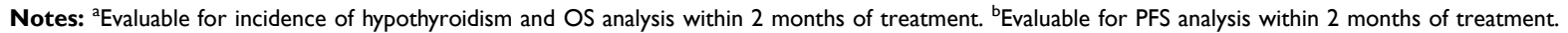
Abbreviations: NG, not given in the study; NR, not reached in the study.

mRCC patients, although conclusions are not uniform in this aspect. ${ }^{5}$ A lot of studies have been carried out on this point and the results show different stories.

The latest study is finished by Vasileiadis et al It is a retrospective analysis focused on sunitinib, indicating that an elevation of TSH may indicate both longer progression-free survival (PFS: 11.92 vs. 8.63 months, $\mathrm{p}=0.0476$ ) and longer overall survival (OS: 3.10 vs. 1.08 years, $\mathrm{p}=0.0011) .{ }^{30}$ According to another study carried out by Bailey et al, in patients developing severe hypothyroidism (TSH $>10 \mathrm{mIU} / \mathrm{L})$ after taking VEGFR-TKIs, the mean PFS was 47.7 months and OS were not reached during their follow-up, much longer than those who had euthyroidism or mild hypothyroidism $(\mathrm{TSH} \leq 10 \mathrm{mIU} / \mathrm{L})$, 
with statistical significance. ${ }^{15}$ In Kust's conclusion, mRCC patients acquiring symptomatic hypothyroidism during their follow-up under the treatment of TKIs experienced significantly longer PFS, but without a difference in OS. Because he found that the OS was not statistically significant in patients with $\mathrm{TSH}>4 \mathrm{mIU} / \mathrm{L}$ and receiving levothyroxine than all other patients (46.0 vs. 22.1 months, $\mathrm{p}=0.2052) .^{5}$ Another study from Wolter et al also found that OS was not statistically significant in patients with acquired hypothyroidism and euthyroid after receiving TKI treatment, whereas PFS was statistically significant. $^{31}$ However, Schmidinger et al suggested that the PFS was not statistically significant when comparing the patients developed hypothyroid and those who kept euthyroid, with a mean PFS of 17.0 vs. 10.8 months $(\mathrm{P}=0.53){ }^{32}$ Besides, a retrospective study, implemented by Sella et al, concluded that hypothyroidism developed in $52 \%$ of their patients treated with sunitinib, maybe associate with a trend toward prolonged PFS and survival, but without statistically significance. ${ }^{21}$

In other studies, when comparing the PFS and OS between patients developed hypothyroidism or not, researchers are more likely to hold that the occurrence of hypothyroidism can suggest a better prognosis, showing longer PFS and OS. ${ }^{19,29,33-36}$ As shown in Table 1.

So far, there is no accurate conclusion as to whether hypothyroidism in the treatment of TKIs of mRCC patients could serve as potential biomarkers of response and efficacy of treatment. But in terms of existing research, most studies found that for patients developing hypothyroidism after treating with VEGF/R-TKIs, PFS was reported to extend with statistical significance. And there is insufficient evidence on whether patients' OS can be extended.

More high-quality, multi-center researches should be implemented to help judge its values and assist in further treatment of hypothyroidism.

Normally, for patients with mRCC, the degree of hypothyroidism that occurs during TKI treatment is usually mild and could be easily treated with thyroid hormone replacement therapy. ${ }^{5}$ Severe hypothyroidism is not common in patients on therapy with sunitinib. However, in some patients, despite the use of thyroid hormone replacement therapy, abnormally high levels of TSH and severe symptoms have emerged, suggesting that severe clinical toxicity is not necessarily accompanied by prolonged survival and may even lead to substantial symptom burden. ${ }^{37}$ However, whether the replacement hormones with L-thyroxine affect patient survival or not, and the relevance of L-thyroxine dose and prognosis deserves further investigation.

\section{Conclusion}

Up to now, most studies hold that hypothyroidism occurring during TKI therapy may serve as potential biomarkers of response and efficacy of treatment, but there is no consensus on this point. The possible reason may lie in the differences in treatment strategies, test indicators, and follow-up time in different studies, may also be due to the poor consistency of studies conducted in different centers and the large variation between groups. There is a clear need for systematic investigation of management strategies for AEs related to targeted therapies for $\mathrm{mRCC}$. Therefore, further studies are needed to determine whether and how hypothyroidism affects the prognosis of $\mathrm{mRCC}$ when treating with TKIs, which could undoubtedly help the doctors to arrange a more reasonable treatment strategy.

\section{Acknowledgments}

No potential conflicts of interest were disclosed.

\section{Disclosure}

The authors report no conflicts of interest in this work.

\section{References}

1. Ljungberg B, Albiges L, Abu-Ghanem Y, et al. European Association of urology guidelines on renal cell carcinoma: the 2019 update. Eur Urol. 2019;75(5):799-810. doi:10.1016/j.eururo.2019.02.011

2. Dabestani S, Marconi L, Hofmann F, et al. Local treatments for metastases of renal cell carcinoma: a systematic review. Lancet Oncol. 2014;15(12):e549-561.

3. Nearchou A, Valachis A, Lind P, Akre O, Sandstrom P. Acquired hypothyroidism as a predictive marker of outcome in patients with metastatic renal cell carcinoma treated with tyrosine kinase inhibitors: a literature-based meta-analysis. Clin Genitourin Cancer. 2015;13 (4):280-286. doi:10.1016/j.clgc.2014.10.002

4. Vitale MG, Bracarda S, Cosmai L, et al. Management of kidney cancer patients: 2018 guidelines of the Italian Medical Oncology Association (AIOM). Tumori. 2019;105(4_suppl):3-12. doi:10.1177/0300891 619853392

5. Kust D, Prpic M, Murgic J, et al. Hypothyroidism as a predictive clinical marker of better treatment response to sunitinib therapy. Anticancer Res. 2014;34(6):3177-3184.

6. Courthod G, Tucci M, Di Maio M, Scagliotti GV. Papillary renal cell carcinoma: a review of the current therapeutic landscape. Crit Rev Oncol Hematol. 2015;96(1):100-112. doi:10.1016/j.critrevonc.2015. 05.008

7. Moore LE, Nickerson ML, Brennan P, et al. Von Hippel-Lindau (VHL) inactivation in sporadic clear cell renal cancer: associations with germline VHL polymorphisms and etiologic risk factors. PLoS Genet. 2011;7(10):e1002312.

8. Kaelin WG Jr. The von Hippel-Lindau tumour suppressor protein: O2 sensing and cancer. Nat Rev Cancer. 2008;8(11):865-873.

9. National Comprehensive Cancer Network. NCCN clinical practice guidelines in oncology:kidney cancer, version 3. 2019. 
10. Escudier B, Eisen T, Stadler WM, et al. Sorafenib in advanced clear-cell renal-cell carcinoma. $N$ Engl $J$ Med. 2007;356 (2):125-134. doi:10.1056/NEJMoa060655

11. Motzer RJ, Hutson TE, Tomczak P, et al. Sunitinib versus interferon alfa in metastatic renal-cell carcinoma. $N$ Engl J Med. 2007;356 (2):115-124.

12. Sternberg CN, Davis ID, Mardiak J, et al. Pazopanib in locally advanced or metastatic renal cell carcinoma: results of a randomized phase III trial. J Clin Oncol. 2010;28(6):1061-1068.

13. Eisen T, Sternberg CN, Robert C, et al. Targeted therapies for renal cell carcinoma: review of adverse event management strategies. J Natl Cancer Inst. 2012;104(2):93-113.

14. Wong E, Rosen LS, Mulay M, et al. Sunitinib induces hypothyroidism in advanced cancer patients and may inhibit thyroid peroxidase activity. Thyroid. 2007;17(4):351-355.

15. Bailey EB, Tantravahi SK, Poole A, et al. Correlation of degree of hypothyroidism with survival outcomes in patients with metastatic renal cell carcinoma receiving vascular endothelial growth factor receptor tyrosine kinase inhibitors. Clin Genitourin Cancer. 2015;13(3):e131-e137.

16. Braun D, Kim TD, le Coutre P, Kohrle J, Hershman JM, Schweizer U. Tyrosine kinase inhibitors noncompetitively inhibit MCT8-mediated iodothyronine transport. J Clin Endocrinol Metab. 2012;97(1):E100-E105.

17. Kamba T, Tam BY, Hashizume H, et al. VEGF-dependent plasticity of fenestrated capillaries in the normal adult microvasculature. $\mathrm{Am}$ J Physiol Heart Circ Physiol. 2006;290(2):H560-H576.

18. Torino F, Corsello SM, Longo R, Barnabei A, Gasparini G. Hypothyroidism related to tyrosine kinase inhibitors: an emerging toxic effect of targeted therapy. Nat Rev Clin Oncol. 2009;6 (4):219-228. doi:10.1038/nrclinonc.2009.4

19. Sabatier R, Eymard JC, Walz J, et al. Could thyroid dysfunction influence outcome in sunitinib-treated metastatic renal cell carcinoma? Ann Oncol. 2012;23(3):714-721. doi:10.1093/annonc/ $\operatorname{mdr} 275$

20. Hercbergs AH, Ashur-Fabian O, Garfield D. Thyroid hormones and cancer: clinical studies of hypothyroidism in oncology. Curr Opin Endocrinol Diabetes Obes. 2010;17(5):432-436.

21. Sella A, Hercbergs AH, Hanovich E, Kovel S. Does sunitinib-induced hypothyroidism play a role in the activity of sunitinib in metastatic renal cell carcinoma? Chemotherapy. 2012;58(3):200-205.

22. Czarnecka AM, Matak D, Szymanski L, et al. Triiodothyronine regulates cell growth and survival in renal cell cancer. Int $J$ Oncol. 2016;49(4):1666-1678. doi:10.3892/ijo.2016.3668

23. Davis PJ, Davis FB, Mousa SA. Thyroid hormone-induced angiogenesis. Curr Cardiol Rev. 2009;5(1):12-16. doi:10.2174/ 157340309787048158

24. Kappers MH, van Esch JH, Smedts FM, et al. Sunitinib-induced hypothyroidism is due to induction of type 3 deiodinase activity and thyroidal capillary regression. $J$ Clin Endocrinol Metab. 2011;96(10):3087-3094. doi:10.1210/jc.2011-1172
25. Liwanpo L, Ro C, Haq S, Hershman JM. Sunitinib does not block thyroid peroxidase in patients. Thyroid. 2014;24(8):1325-1326. doi: $10.1089 /$ thy. 2014.0006

26. Mannavola D, Coco P, Vannucchi G, et al. A novel tyrosine-kinase selective inhibitor, sunitinib, induces transient hypothyroidism by blocking iodine uptake. J Clin Endocrinol Metab. 2007;92 (9):3531-3534.

27. Salem AK, Fenton MS, Marion KM, Hershman JM. Effect of sunitinib on growth and function of FRTL-5 thyroid cells. Thyroid. 2008; 18:5.

28. de Groot JW, Links TP, van der Graaf WT. Tyrosine kinase inhibitors causing hypothyroidism in a patient on levothyroxine. Ann Oncol. 2006;17(11):1719-1720. doi:10.1093/annonc/mdl112

29. Baldazzi V, Tassi R, Lapini A, Santomaggio C, Carini M, Mazzanti R. The impact of sunitinib-induced hypothyroidism on progression-free survival of metastatic renal cancer patients: a prospective single-center study. Urol Oncol. 2012;30(5):704-710. doi:10.1016/j.urolonc.2010.07.015

30. Vasileiadis T, Chrisofos M, Safioleas M, Kontzoglou K, Papazisis K, Sdrolia A. Impact of sunitinib-induced hypothyroidism on survival of patients with metastatic renal cancer. BMC Cancer. 2019;19(1):407. doi:10.1186/s12885-019-5610-8

31. Wolter P, Stefan C, Decallonne B, et al. Evaluation of thyroid dysfunction as a candidate surrogate marker for efficacy of sunitinib in patients (pts) with advanced renal cell cancer (RCC). J Clin Oncol. 2008;26(15_suppl):5126. doi:10.1200/jco.2008.26.15_suppl.5126

32. Schmidinger M, Vogl UM, Bojic M, et al. Hypothyroidism in patients with renal cell carcinoma: blessing or curse? Cancer. 2011;117 (3):534-544.

33. Buda-Nowak A, Kucharz J, Dumnicka P, et al. Sunitinib-induced hypothyroidism predicts progression-free survival in metastatic renal cell carcinoma patients. Med Oncol. 2017;34(4):68. doi:10.1007/s12032-017-0928-z

34. Pinto FAI, Pereira AAR, Formiga MN, et al. Association of hypothyroidism with improved outcomes in first-line treatment of renal cell carcinoma with sunitinib. $J$ Clin Oncol. 2012;30 (5_suppl):466.

35. Clemons J, Gao D, Naam M, Breaker K, Garfield D, Flaig TW. Thyroid dysfunction in patients treated with sunitinib or sorafenib. Clin Genitourin Cancer. 2012;10(4):225-231. doi:10.1016/j. clgc.2012.08.002

36. Riesenbeck LM, Bierer S, Hoffmeister I, et al. Hypothyroidism correlates with a better prognosis in metastatic renal cancer patients treated with sorafenib or sunitinib. World J Urol. 2011;29 (6):807-813. doi:10.1007/s00345-010-0627-2

37. Del Fabbro E, Dev R, Cabanillas ME, Busaidy NL, Rodriguez EC, Bruera E. Extreme hypothyroidism associated with sunitinib treatment for metastatic renal cancer. $J$ Chemother. 2012;24(4):221-225.

\section{Publish your work in this journal}

Drug Design, Development and Therapy is an international, peerreviewed open-access journal that spans the spectrum of drug design and development through to clinical applications. Clinical outcomes, patient safety, and programs for the development and effective, safe, and sustained use of medicines are a feature of the journal, which has also been accepted for indexing on PubMed Central. The manuscript management system is completely online and includes a very quick and fair peer-review system, which is all easy to use. Visit http://www. dovepress.com/testimonials.php to read real quotes from published authors. 